\title{
Johannes Calvyn as pedagoog
}

\author{
S Schoeman \\ Universiteit van Suid-Afrika
}

\begin{abstract}
John Calvin as pedagogue

Calvin was not only a theologian, but a competent pedagogue as well. He set a high value on education, and promoted it actively, but never systematically committed his views on it to paper. His educational views were not purely educational, but connected to a particular theological view. It is nevertheless possible to construct the broad general principles upon which his educational philosophy is based, from three sources: these are data on his educational activities in Geneva, the educational opinions that appeared in his writings, and the implications of his theological views for education.
\end{abstract}

\section{INIEIDEND}

Alhoewel Calvyn (1509-1564) hoë waarde aan die onderwys geheg en dit daadwerklik bevorder het, het hy sy idees daaroor nie op 'n sistematiese wyse geboekstaaf nie. Trouens, sy uitsprake in hierdie verband was nooit suiwer onderwyskundig gefundeer nie, maar altyd aan 'n besondere teologiese ingesteldheid gekoppel. Turkstra (1978:20) haal Hedtke aan wat die onderwysuitsprake van Calvyn om hierdie rede as 'n Begleit-melodie van sy teologie beskryf.

Dit is egter moontlik om Calvyn se onderwyssiening uit drie bronne te konstrueer, naamlik uit gegewens aangaande sy onderwyswerksaamhede in Genève, sy onderwysuitsprake soos blyk uit sy geskrifte en deur die implikasies van sy teologiese opvattinge vir die onderwys te ontleed. Hoewel genoemde drie bronne geensins 'n volledige beeld van Calvyn se onderwysfilosofie bied nie, verskaf dit tog kennis aangaande die breë algemene beginsels warop dit berus (Coetzee 1959:197; Van der Walt 1981:2). Elkeen van genoemde drie kenbronne word vervolgens ontgin ten einde Calvyn se status as pedagoog aan te toon. 


\section{CALVYN SE ONDERWYSOPVATTINGE SOOS BLYK UIT SY ONDER- WYSWERKSAAMHEDE IN GENèVE}

\subsection{Die Geneefse onderwys en sy eerste verblyf in Genève (1536-1538)}

Toe Calvyn in 1536 in Genève begin werk het, het hy met kerklike ampsdraers en burgers, sonder 'n presiese kennis van die Christelike dogma te doen gekry - 'n kennis wat hy as fundamenteel vir die geloofslewe in die besonder en vir die alledaagse lewe in die algemeen beskou het. Hy het ook die nood aan behoorlik onderlegde kerklike ampsdraers vir die oordra van die Bybelse kennis en die geloofswaarhede besef (Scholtemeijer 1953:52; Towns 1975:168).

In Mei van daardie jaar het hy 'n voorstel vir beperkte kerkordenende reëls aan die inwoners van Genève voorgelè waarby planne vir 'n skool ingesluit was (McNeill 1954:138). Die gevolg daarvan was die stigting in 1536 van die Collëge de la Rive. Guillaume Farel (1489-1565) is as skoolhoof aangestel. Skoolbywoning was verpligtend en die behoeftiges is van die betaling van skoolgeld vrygestel. Onderrig is in lees, skryf, rekenkunde, grammatika en godsdiens gegee. Wat laasgenoemde betref, het Farel die Ou Testament en Calvyn (op 'n deeltydse hasis) die Nuwe Testament behartig (Towns 1975:168).

In samewerking met Farel het hy in Januarie 1537 op versoek van die Geneefse owerheid Artikels (Articles concemant l'organisation de l'eglise) aan hulle voorgelè waarin die organisasie van die gemeentelewe beskryf is (Van den Brink \& Dankbaar 1967:156). Hierin (art 3) het hy ook aan die noodsaaklikheid van sowel godsdiensonderwys as sekulère onderwys aandag gegee (Cadier 1960:85). Wat godsdiensonderwys betref, moes die kinders vir een uur elke dag Psalms sing ten einde die kerksang op Sondae te verbeter. Ouers moes aan hulle kinders tuis 'n kort en eenvoudige uiteensetting van die Christelike geloof leer sodat hulle voor die predikant rekenskap van hulle geloof kon gee (Kotze 1935:308). Sekulère onderwys is verpligtend gemaak deur neer te lê dat ouers gestraf kon word indien hulle geweier het om hulle kinders skool toe te stuur of as hulle hulle kinders se onderwys verwaarloos het (Coetzee 1959:200).

In Januarie 1538 het Calvyn in samewerking met Martin Cordier (1479-1564) 'n Prospektus insake die openbare skole (die laer- en hoërskole) in Genève uitgegee. Die doel daarmee was onder meer om ook die Collège de la Rive te hervorm. In dié dokument is die volgende gegewens vervat: Die hoof van die skool moes ' $n$ bekwame persoon wees, twee assistente moes hom bystaan, behoeftige kinders moes (vanweè die ruim besoldiging van die skoolhoof) gratis onderwys ontvang en omdat die Reformasie slegs kon groei en toeneem deur 'n studie van die teologie, kuns en wetenskap, moes die kinders daarin onderrig word. In die Prospektus is ook verklaar dat onderrig in die sekulère vakke net so noodsaaklik as godsdiensonderrig is. 
Nietemin is daarop gewys dat die Woord van God die fondament van alle onderrig is en dat die sekulère vakke as hulpmiddel moes dien om eersgenoemde beter te verstaan. 'n Gimnasium of kollege moes gevolglik in die lewe geroep word waar die kinders vir sowel die kerklike as die burgerlike ampte voorberei kon word (Coetzee 1959:201).

\subsection{Sy pedagogiese betrokkenheid in Straatsburg (1538-1541)}

$\mathrm{Na}$ 'n stryd teen sowel die teenstanders van die Protestantisme as mede-Protestante het Calvyn en Farel Genève in Mei 1538 verlaat en hul in Basel gaan vestig (Parker 1975:66). Hier het Calvyn 'n uitnodiging van Martin Bucer (1491-1551) ontvang om die predikant van die Franse Protestantse vlugtelinge in Straatsburg te word (Dankbaar 1957:57). Calvyn is ook 'n pos as onderwyser aan Johannes Sturm (1507-1589) se Akademie ('n sekondère skool) aangebied. In Januarie 1539 het hy begin om teologie aldaar te doseer (Parker 1975:69). Sy verbintenis met dié Akademie was vir hom van groot pedagogiese waarde, want hier het hy baie omtrent die skoolorganisasie en die kognitiewe vermoëns van die kind geleer (Coetzee 1959:202).

\subsection{Die Geneefse onderwys en sy tweede verblyf in Genève (1541-1559)}

\subsubsection{Die periode voor die Geneefse Akademie (1541-1556)}

$\mathrm{Na}$ 'n periode van wanorde in Genève het die stadsvaders gevoel dat Calvyn (wat toe as een van die belangrikste Franse Protestante beskou is) daarheen moes terugkeer on die kerk en die staat van ondergang te red (Doumergue 1931:11). Met sy terugkeer na Genève in 1541 het hy onmiddellik begin om die Articles 1537 te hersien. Dié hersiene Articles is aan die Geneefse owerheid vir goedkeuring voorgelè. $\mathrm{Na}$ 'n deeglike bespreking en enkele wysiginge is dit in November 1541 amptelik aanvaar en in dieselfde jaar as die Ordonnances écclesiastiques gepubliseer (Dankbaar 1957:84).

Volgens dié Kerkorde moes daar vier soorte ampte (soos deur Jesus Christus ingestel) in die kerkregering wees, naamlik dié van die predikant, dié van die doktor (professor of onderwyser), dié van die ouderling en dié van die diaken (Dankbaar 1957:86). Die pligte van elke ampsdraer is duidelik omskryf (Scholtemeijer 1953: 66). Vir die doel van hierdie artikel word vervolgens net na die amp en pligte van die doktor (professor of onderwyser) verwys.

Die onderwys het onder die gesag van die kerk geressorteer. Die doktore (professore of onderwysers) was daarom kerklike ampsdraers. Die kerk moes die onderwys (veral godsdiensonderwys) doelbewus bevorder, omdat dit 'n belangrike rol in die godsdienstige vorming van die gemeenskap vervul het (Dankbaar 1957:88). Die onderwyser se primère taak was om die kinders van gelowiges in die Ou en Nuwe 
Testament te onderrig sodat die suiwerheid van die evangelie nie deur valse leringe of onkunde besoedel word nie. Godsdiensonderwys is egter waardeloos indien die leerlinge nie vantevore sekulère onderrig (in tale en die geesteswetenskappe) ontvang het nie (Coetzee 1959:203-204).

In dié Kerkorde is ook daarop gewys dat dit noodsaaklik is om nou die 'saad' vir die toekoms te saai. Daarom moes skole gestig word waar die kinders vir sowel die kerklike as die burgerlike ampte voorberei kon word. Allereers sou 'n geskikte skoolterrein en -geboue en 'n geleerde en bekwame skoolhoof en 'n onderwyser gevind moes word. Die dogters moes soos voorheen afsonderlike skole bywoon. Leerlinge sou slegs tot die skole toegelaat word indien hulle 'n getuigskrif van goeie sedelike gedrag van die predikant voorlè. Geen ander skole sou in die stad toegelaat word nie (Parker 1975:83).

Op grond van sy onderwyservaring in Straatsburg het Calvyn met sy terugkeer na Genève gevoel dat die Kategismus van 1537 nie as leerboek vir kinders geskik is nie en besluit om dit in vraag- en antwoordvorm te herskryf. Die hersiene uitgawe het in 1545 verskyn (Walker 1967:275). In die voorwoord het hy gewaarsku dat 'the world is threatened with...barbarianism and the church with fearful ruin...' (Calvyn 1958:35). Die regstelling hiervan was vir hom deels in die onderwys geleë (Calvyn 1958:36).

2.3.2 Die stigting, organisasie en administrasie van die Geneefse Akademie (1556-1559)

\subsubsection{Stigting}

In 1556 het Calvyn weer 'n besoek aan die Akademie in Straatsburg gebring waartydens hy sy onderwysideaal (om 'n soortgelyke inrigting in Genève op te rig) met sy voormalige kollegas bespreek het (Walker 1967:361; Scholtemeijer 1953:94). Met sy terugkeer na Genève (1556) het hy in alle erns begin om die laerskole te herorganiseer, maar as gevolg van politieke onrus in Genève kon hy nie onmiddellik sy onderwysideaal (die stigting van 'n Akademie) verwesenlik nie (Dankbaar 1957:136; Walker 1967:361). Reid (s a:8) skryf in dié verband: 'From 1541 to 1556 there was a continual battle to maintain the reformed church against the attack of the Libertines, Romanists, and politicians, so that little time could be spent in improving the schools.'

Nadat bogenoemde omstandighede verbeter het, het Calvyn tot die stigting van die beoogde Akademie oorgegaan. Die skoolgebou waarin die Collège de la Rive gehuisves was, was vervalle en onbruikbaar, gevolglik het hy die owerheid gevra om te help om df eersgenoemde te vergroot en te verbeter of om 'n nuwe skoolgebou op te rig (Dankbaar 1957:137). Die owerheid het 'n erf in die ou stad vir die oprig- 
ting van 'n nuwe skoolgebou beskikbaar gestel, maar kon nie die oprigting van die gebou finansier nie (Parker 1975:127). Vir laasgenoemde het Calvyn donateurs gesoek en fondsinsamelingspogings geloods (Dankbaar 1957:137). Nadat die skoolgebou voltooi is, het Calvyn nie alleen net onderneem om reëls vir die skool op te stel nie, maar ook om geskikte personeel te werf (Walker 1967:361). Die reëls vir die skool het in 1559 as die Leges Academiae Genevensis (Reëls vir die Geneefse Akademie) verskyn. As inleiding tot die Leges is 'n beskrywing van die openingseremonie van die Akademie gegee (Parker 1975:128).

Die Akademie is op 5 Junie 1559 in die Sint Pieterskerk geopen. Die program het soos volg daaruit gesien: Calvyn het die verrigtinge met 'n toespraak en 'n gebed geopen. Vervolgens het Michael Roset, die stadsekretaris, die Reëls vir die Akademie, 'n geloofsbelydenis en 'n eed voorgelees, waarna al die dosente laasgenoemde in die openbaar afgelê het (Coetzee 1959:205-206). Die name van die aangestelde professore en onderwysers is amptelik aangekondig. Die professore was Theodorus Beza (rektor), Antonius Cevallanius (professor in Hebreeus), Franciscus Beraldus (professor in Grieks), Johannes Tagantius (professor in Lettere) en Johannes Calvyn (professor in teologie op 'n weeklikse roterende basis met Beza). Die onderwysers (vir die sewe klasse van die schola privala kyk 2.3.2.2) was (Coetzee 1959:206):

* Klas 1 - Johannes Rendonius;

- Klas 2 - Carolus Malbueus;

- Klas 3 - Johannes Barbirius (ook hoof van die schola privata);

* Klas 4 - Gervasius Enaltus;

- Klas 5 - Petrus Dux;

- KJas 6 - Johannes Perrilius;

- Klas 7 - Johannes Laureatus.

Hierna het Theodorus Beza (die rektor) die openingsrede gehou (Scholtemeijer 1953:95). Nadat hy die geskiedenis van hoër onderwys geskets het, het hy die studente toegespreek: 'Gij zijt hier gekomen om, na onderwezen te zijn in de ware religie en in de kennis der schone letteren, te kunnen werken voor de eer van God, om eenmaal tot steun van uw medemensen te kunnen worden en uw vaderland eer aan te doen. Houdt altijd in herinnering, dat gij soldaten zijt en aan uw hoogste Bevelhebber rekenschap zult hebben af te leggen van deze heilige opdracht' (Dankbaar 1957:138).

Ten slotte het Calvyn 'n woord van dank teenoor die owerheid vir sy aandeel in die totstandkoming van die Akademie uitgespreek en die verrigtinge met 'n gebed afgesluit (Scholtemeijer 1953:95). 


\subsubsection{Organisasie en administrasie}

Die Akademie is in twee afdelings verdeel, te wete die schola privata (vir kinders tot sestien jaar) en die schola publica (die universiteit; Cadier 1960:165). By elkeen van dié afdelings gaan vervolgens kortliks stilgestaan word. Daarbenewens sal ook na enkele algemene onderwysaangeleenthede gekyk word.

\subsection{Die schola privata}

\section{* Personeel}

- Die hoof

Die hoof van die skool moes godvresend, selfbeheersd, geleerd, gelykmatig van geaardheid en 'n voorbeeld vir sy leerlinge wees. Hierbenewens moes hy ook 'n aantreklike voorkoms hê en nie lomp wees nie. Dit was sy taak om toesig oor die gedrag en pligsgetrouheid van sy kollegas te hou, by alle openbare strafuitoefening teenwoordig te wees, die skoolklok betyds te lui, te sorg vir die netheid van die klaskamers, toe te sien dat geen onderwyser sonder sy toestemming iets vreemds in die leerplan invoer nie en aan die rektor van die Akademie verslag te doen.

\section{- Die onderwysers}

Die onderwysers is deur 'n kieskollege (bestaande uit professore en predikante) gekeur en deur die owerheid aangestel (Coetzee 1959:208). Elke onderwyser moes by aanstelling die geloofsbelydenis van die Kerk van Genève onderteken en het onder die gesag van die kerk gestaan (Coetzee 1959:211). Van die onderwysers is verwag om vroeg in hulle klaskamers te wees, nie hulle werk te verwaarloos nie, die hoof betyds in kennis te stel indien hulle afwesig sou wees sodat of 'n plaasvervanger of inskakeling by 'n ander klas gereël kon word, selfbeheersd, godvresend en waardig in gedrag en houding te wees, 'n afsku van sonde te hê, studiemateriaal objektief oor te dra en enige onduidelikheid uit die weg te ruim, nie hulle klasse sonder 'n goeie rede te verlaat nie en betyds te verdaag, alle dogmatiese verskille tussen kollegas onder die aandag van die rektor te bring wat dit dan op sy beurt na die kieskollege sal verwys en streng oor die leerlinge se leer en lewe toesig te hou.

\section{* Klasindeling}

Die skool is in sewe klasse ingedeel, beginnende met Klas Sewe en eindigende met Klas Een. Elke onderwyser het eweveel leerlinge gehad. Die leerlinge is volgens hulle vermoëns en ontwikkeling in groepe van tien elk gegroepeer. Die leier van elke groep het op die voorste sitplek plaasgeneem en die ander groeplede deurentyd dopgehou (Coetzee 1959:209). 
** Godsdiensonderwys en erediensbywoning

Die owerheid het aan elke leerling 'n sitplek in die kerk toegewys waarop hy/sy tydens die een uur godsdiensonderwysperiode op Woensdae en tydens die kerkdienste in die middae en op Sondagoggende moes sit. 'n Onderwyser moes by elke kerkdiens teenwoordig wees om toesig oor die kinders se gedrag te hou en die presensielys (indien nodig) na afloop van die erediens na te gaan. 'n Aantekening moes van die leerlinge wat nie aandagtig geluister het nie, gemaak word.

\section{** Skoolprogram en leerinhoud}

Die skool het om ses-uur in die somer en sewe-uur in die winter begin en om vieruur namiddag gesluit. Van Maandae tot Vrydae het die dag se program met die opsê van gebede uit die Kategismus (die leerlinge het beurte gemaak om dit op te sê) en die hou van 'n presensielys begin (Coetzee 1959:208). Leerlinge wat met 'n goeie rede afwesig was, is verskoon, maar al die ander afwesiges is die volgende dag gestraf.

Die skoolprogram het verder min of meer soos volg daaruit gesien: 'n les van negentig minute, ' $n$ pouse van dertig minute, dan weer 'n les van sestig minute gevolg deur die opsê van die Ons Vader en 'n dankgebed, dan 'n pouse vir ontbyt (dertig minute) gevolg deur die sing van Psalms vir sestig minute, dan weer 'n les vir sestig minute, middagete (negentig minute) en godsdiensoefening (dertig minute). Die skooldag is met 'n byeenkoms in die saal afgesluit waartydens die Ons Vader en die geloofsbelydenis opgesê, 'n deel van die Tien Gebooie gelees en bestraffing plaasgevind het. Ten slotte het die hoof die byeenkoms met 'n gebed afgesluit.

Op Woensdae is 'n erediens en openbare lesings bygewoon, 'n klasdebat gehou, opstelle oor voorgeskrewe onderwerpe geskryf en 'n geleentheid vir speeltyd (sestig minute) ingeruim. Saterdae is al die week se lesse hersien en 'n openbare debat gehou. Die hele Sondag is aan die erediens en die nabetragting daarvan gewy.

Altesaam sewentig lesse (uitgeslote die hersieningslesse) is per week aangebied. In die week wat die Nagmaal voorafgegaan het, het een van die predikante dié sakrament aan die leerlinge kom verduidelik en op die deugde van eerbied en eensgesindheid gewys (Coetzee 1959:209).

Die leerinhoud het uit lees, skryf, godsdiensonderwys, Frans, Latyn, Grieks, Romeinse geskiedenis, dialektiek, etiek en retoriek bestaan (Dankbaar 1957:137). 


\subsection{Die schola publica}

** Personeel en studente

- Die rektor

Die hele Akademie (maar in die besonder die schola publica) het onder die beheer en toesig van die rektor (Theodorus Beza, wat vir 'n termyn van twee jaar deur die kieskollege verkies is) gestaan. Hy is deur die owerheid voorgestel en ingehuldig en moes 'n toegewyde en geleerde persoon wees (Towns 1975:170). Sy take het onder meer ingesluit die administrasie van beide skole, beslegting van onmin tussen studente, advisering van die studente oor die bywoning van die lesings, uitreiking van getuigskrifte ten opsigte van die gedrag en vordering van die studente, byeenroeping (met die goedkeuring van die owerheid) van spesiale byeenkomste, keuring van studente, toekenning van grade en toesighouding oor die werksaamhede van die schola privata en die ywer van die professore (Coetzee 1959:206-207).

\section{- Die professore}

Die professore is op presies dieselfde wyse as die rektor verkies, voorgestel en ingehuldig en moes op gesette tye voorgeskrewe lesings in hulle spesifieke vakrigtings aanbied (Coetzee 1959:207).

\section{- Die studente}

Studente wat beoog het om by die schola publica in te skryf, moes hulle name by die rektor opgee en 'n geloofsbelydenis onderteken (Walker 1967:365). Van hulle is verwag om vroom en beskeie te wees (Dankbaar 1957:139).

Die name van die teologiese studente is op 'n afsonderlike lys geplaas. In die volgorde waarop hulle name op dié lys verskyn het, moes hulle op Saterdagmiddae tussen twee-uur en drie-uur 'n Skrifgedeelte onder die wakende oog van 'n predikant eksegetiseer. Die aanwesiges kon kritiek daarop lewer. Die studente moes ook maandeliks volgens ' $n$ vaste rooster 'n opstel oor 'n teologiese onderwerp skryf. Kettery en pedanterie moes daarin vermy word. Dié opstelle is met die professor in teologie bespreek en mondelings onder sy leiding tydens 'n openbare byeenkoms vanuit elke moontlike hoek bekyk. Alle aanwesiges kon aan dié bespreking deelneem (Towns 1975:171).

\section{** Onderrigprogram en leerinhoud}

Elke week is sewe en twintig lesings van 'n uur elk gegee, te wete drie in teologie, agt in Hebreeus, drie in Griekse etiek, vyf in Griekse retoriek of poësie, drie in kuns, liggaamsopvoeding en natuurkunde of wiskunde en vyf in dialektiek. Almal wat wou, kon die lesings gratis bywoon. 
Op Maandae, Dinsdae en Donderdae is vir honderd en twintig minute lank onderrig gegee, terwyl op Woensdae en Vrydae slegs vir sestig minute in die middag onderrig verskaf is. Vrydae was die bywoning van kerkbyeenkomste verpligtend. Saterdae is geen lesings gegee nie en op Sondae is die kerkdienste bygewoon.

Die professore in teologie moes die Bybel op Maandae, Dinsdae en Donderdae verklaar (Towns 1975:171-172). Die professor in Hebreeus moes net na die formele opening in die oggend ' $n$ boek van die Ou Testament eksegetiseer. In die middag het die Hebreeuse grammatika aan die beurt gekom. Onderrig in Grieks het uit die volgende bestaan: Tydens die oggendlesings is 'n wysgerige onderwerp, soos byvoorbeeld die etiek van Plato, Aristoteles, Plutargus of van een van die Christenfilosowe behandel en in die middae is 'n lesing oor 'n Griekse digter, redenaar of historikus aangebied (Coetzee 1959:208). Die professor in lettere het kuns, liggaamsopvoeding en natuurkunde of wiskunde onderrig. Die latere byvoeging van geneeskunde en regte is in die vooruitsig gestel (Nixon 1963:131).

\section{** Bevordering van die leerlinge}

In die schola privata is die bevordering van die leerlinge as 'n gewigtige saak beskou. Aan die einde van elke skooljaar (sowat drie weke voor 29 April) moes alle leerlinge om twaalf-uur in die saal vergader waar een van die professore 'n lesing in Frans gegee het. Die leerlinge moes ooreenkomstig hul vermoëns na die inhoud van die lesing luister. Na afloop van die lesing het die leerlinge na 'n ander klaskamer gegaan waar hulle die hoofpunte van die lesing in Latyn moes opsom. As gevolg van sy siening van die erfsonde het Calvyn daarop aangedring dat die onderwysers in die klaskamers moes bly terwyl die leerlinge hulle opsommings neerskryf. Die opsommings is vervolgens versamel, in groepe van tien gerangskik en na die rektor geneem. In die daaropvolgende dae het laasgenoemde, in oorleg met die betrokke professor, die opsommings van die verskillende klasse volgens verdienstelikheid gerangskik. Die leerlinge is daarna individueel ingeroep, op hulle foute gewys en verder deur die eksaminatore (die rektor en die professor) ondervra. Laasgenoemde het daarna besluit wie bevorder moes word.

Op 1 Mei (as dit op 'n Sondag val, die volgende dag) het die hele skool op die Sint Pieterskerkplein bymekaar gekom. By dié geleentheid het die rektor die Leges voorgelees en kortliks verduidelik. Die twee beste presteerders het elk 'n prys van die owerheid ontvang. Dié twee leerlinge moes laasgenoemde daarna met die nodige respek bedank. Die rektor het hulle vervolgens met hulle goeie werk gelukgewens (Coetzee 1959:210). Die leerlinge van die eerste en tweede klasse moes daarop hulle opstelle hardop voorlees. Ten slotte het die rektor die verrigtinge met 'n kort gebed afgesluit. 
Benewens hierdie bevorderings is daar ook vir tussentydse bevorderings (tussen 1 Mei en 1 Oktober) voorsiening gemaak. 'n Onderwyser kon dit onder die aandag van die hoof bring dat ' $n$ betrokke kind vir spesiale bevordering oorweeg moes word deur sy naam in 'n boek te skryf. Op 1 Oktober het die rektor al dié kandidate met die professore bespreek, waarna die bevorderingsprosedure in werking gestel is.

\section{** Skoolvakansies}

Drie weke skoolvakansie is gedurende die periode tussen die druiwe-oes en die maak van die wyn toegestaan. Die dag waarop die bevorderings plaasgevind het (1 $\mathrm{Mei}$ ), was ook 'n skoolvakansiedag. Die professore het die eerste Vrydag van die maand vakansie gekry om die openbare debat by te woon (Coetzee 1959:211).

\section{CALVYN SE ONDERWYSUITSPRAKE SOOS BLYK UIT SY GESKRIFTE}

Op sowel direkte as indirekte wyse het Calvyn sy opvattinge oor die grondslag, uitgangspunt en noodsaaklikheid van onderwys, onderwysdoelstelling en leerinhoud, onderwysbeheer en toesighouding, onderwysmetodes, dissipline en interne skoolorganisasie en -administrasie in sy geskrifte verwoord.

\subsection{Grondslag, uitgangspunt en noodsaaklikheid van onderwys}

Calvyn het die gesag van die Bybel in alle sfere van die mens se lewe, dus ook in die onderwys, aanvaar (Calvyn 1960c:220-221). Die onderwysbeginsels moes daarom uit die Bybel afgelei word. In die Prospektus van 1538 het hy bepaal dat die Woord van God die fondament van alle kennis is. Die Bybel moet daarom die grondslag en middelpunt van alle onderwys wees, want alleen deur die suiwere kennis daarvan is die mens bekwaam om sy plek in die wêreld (die owerheid, die kerk en die gemeenskap) in te neem (Scholtemeijer 1953:95).

Fundamenteel ten opsigte van Calvyn se onderwysfilosofie was sy siening van die mens se natuur. Hieroor het hy volledig in sy Institusie gehandel. Hy het die mens (kind) as verdorwe, maar nietemin as opvoedbaar beskou omdat 'n skaduwee van God se beeld na die sondeval in hom oorgebly het (Calvyn 1960b:240). Van al die skepsels van God is die mens die enigste wat in die ware sin van die woord onderrig kan word. Die mens bly 'n opvoedeling dwarsdeur sy lewe. Hy begin sy lewe as 'n onrype wese. Groei en wording is deel van die menslike natuur wat deels fisies en deels geestelik is. Onderwys en opvoeding het met beide te doen, maar primêr met die groei en wording van laasgenoemde (Coetzee 1959:214).

Calvyn het die onderwys in die Articles 1537 as belangrik, selfs as noodsaaklik beskou en hom daarvoor beywer dat alle kinders (seuns sowel as dogters) onderrig in die grondliggende waarhede van die Christelike godsdiens ontvang sodat hulle 
hulle geloof kon bely. Om die noodsaaklikheid van onderwys verder te beklemtoon, het hy die volgende redes aangevoer: ter wille van goeie openbare administrasie, die handhawing en uitbouing van die Christendom, die bevordering en behoud van menslikheid en die versekering van die kind - Godgegewe, maar onvolmaak en sondig - se kultivering. Buitendien het God 'n verbond met die gelowige ouer opgerig wat met die doop in vervulling tree en wat die ouer verplig om sy kind in die vrees van die Here op te voed en te laat opvoed. Die kinders moes dus skoolgaan om onderrig in die Heilige Skrif te ontvang sodat hulle rekenskap van hulle geloof kon gee (Coetzee 1959:201).

\section{Onderwysdoelstelling en leerinhoud}

Die aanhef van Calvyn se Kategismus van 1545 is tiperend van die onderwysdoelstelling wat hy gehuldig het. Genoemde werk het naamlik soos volg begin (Harper 1966:182):

Master: What is the chief end of human life?

Scholar: To know God by whom men were created.

Master: What reason have you for saying so?

Scholar: Because he created us and placed us in this world to be glorified in us. And it is indeed right that our life, of which himself is the beginning, should be devoted to his glory.

Master: What is the highest good of man?

Scholar: The very same thing.

Die eer van God is dus die doel van die mens se lewe en gevolglik ook die doel van die onderwys (Singer 1977:56).

Net soos wat hy 'n duidelike onderwysdoel daarop nagehou het, het Calvyn ook vaste opvattinge oor die leerinhoud gehad. In sy Institusie het hy tussen twee soorte kennis onderskei: kennis van God en kennis van die skepping - onsself (Calvyn 1960a:1). Op grond van dié twee soorte kennis het Calvyn ook tussen twee soorte onderwys onderskei: religieuse en sekulère onderwys (Coetzee 1959:217).

In sy Voorstel van 1536 het Calvyn aanbeveel dat grammatika, lees, skryf, rekenkunde en godsdiensonderwys as leerinhoud gebruik moes word. In die Prospektus van 1538 het hy neergelê dat die kinders in die eerste beginsels van die teologie, kuns en wetenskap onderrig moes word. Calvyn het ook daarop gewys dat sekulêre onderwys net so belangrik soos godsdiensonderwys is, want religieuse kennis en onderwys is die kern van alle sekulère kennis en onderwys. Die sekulêre vakke is 'n hulpmiddel tot ware en vollediger kennis van God en Sy Woord. Alle sekulère onderwys het dus ook die eer van God ten doel (Coetzee 1959:19). Calvyn het dit só gestel: '[T]hose arts...that have nothing of superstition, but contain solid learning 
and are founded on just principles...no doubt...have come forth from die Holy Spirit; and the advantage which is derived and experienced from them, ought to be ascribed exclusively to God' (Calvyn 1949a:73).

Die Leges van 1559 het volledige besonderhede oor die leerinhoud wat in die Geneefse Akademie onderrig is, verstrek. In die schola privata is lees, skryf, godsdiensonderwys, die moedertaal (Frans), die kultuurtale (Latyn en Grieks), Romeinse geskiedenis, etiek, dialektiek en retoriek onderrig. In die schola publica het die leerinhoud uit teologie, die antieke tale (Grieks en Hebreeus), kuns, liggaamsopvoeding en wetenskap (natuurkunde, wiskunde, etiek, dialektiek en retoriek), met die latere byvoeging van geneeskunde en regte, bestaan (Coetzee 1959:219).

\subsection{Onderwysbeheer en toesighouding}

In Genève het daar 'n goed gevestigde samelewingstruktuur bestaan. Volgens die Kerkorde wat Calvyn in 1541 opgestel het, is die beheer van en toesighouding oor die onderwys wel in die hande van die owerheid geplaas, maar dit was meer nominaal as werklik (Eby 1931:24). Genève was 'n teokrasie (Singer 1977:60). Die kerk en staat het twee kante van dieselfde muntstuk gevorm, want hulle oorsprong en gesag was van dieselfde bron (God, die Skepper) afkomstig. Die owerheid se funksie was daarom deels 'to cherish and support the external worship of God, to preserve the pure doctrine of religion, [and] to defend the constitution of the church...' (Calvyn 1949b:634).

Die eintlike beheer van en toesighouding oor die onderwys het by die kerk berus. Al die skoolhoofde en baie van die onderwysers was predikante. Die verteenwoordigers van die kerk het gevolglik prominente posisies in die beheerrade en tydens inspeksies beklee (Marique 1926:18). Volgens Towns (1975:168) het Calvyn die beherende en toesighoudende taak van die kerklike ampsdraers soos volg omskryf:

[T]o discover experimently whether the believer...teaches his children constantly as a Christian should do and sends them to school...the home of every citizen, the most prominent as well as the least stand open at all times for the members of the consistorium.... [A]t least once a year...shall every residence in the city be visited, in order to gain information through questions, examinations and observations in regard to the religious training.

Die ouers het geen rol in die beheer van en toesighouding oor die onderwys gespeel nie. Hulle moes slegs vir twee sake sorg: hulle moes hulle kinders die eerste beginsels van die Christelike godsdiens volgens die Kategismus leer en hulle gereeld skool toe stuur (Alexander 1926:86). 
3.4 Onderwysmetodes, dissipline en die interne skoolorganisasie en -administrasie Calvyn het homself nie pertinent oor die onderwysmetodes uitgelaat nie. Nogtans het hy in sy Institusie vir die geestelike groei en ontwikkeling van die mens, die krag van die Heilige Gees, die onmisbaarheid van die persoonlike geloof, selfverloëning, gebed, oorpeinsing, goeie werke en volharding as algemene onderwysmetodes en/of -ingesteldhede getipeer en beklemtoon (Calvyn 1960b:6, 7, 184, 185, 211, 226, 377). Die spesifieke onderwysmetodes waarvan in die Leges melding gemaak is, was in die schola publica selfstudie, die skryf van opstelle en openbare besprekings en lesings, terwyl die lesingmetode, voordrag, drilwerk, memorisering, die vraag-en-antwoordmetode, hersiening en debattering die onderwysmetodes was wat in die schola privata gebruik is.

Volgens Calvyn is dissipline 'n onontbeerlike faset van die onderwys. In die $A r$ ticles 1537 is dit neergelê dat ouers aangespreek moes word indien hulle nie hulle kinders gereeld vir kategese kerk toe stuur nie. In die Leges van 1559 is streng dissipline oor sowel onderwysers as kinders voorgeskryf. Ontrouheid van leerlinge, onoplettendheid in die klas, ongehoorsaamheid en afwesigheid van kerk en skool moes in die meeste gevalle in die teenwoordigheid van die hele skool gestraf word (Coetzee 1959:219). Uitlatings oor dissipline (gesag) het 'n prominente plek in Calvyn se Institusie ingeneem (Calvyn 1960c:555-595).

Calvyn het besondere aandag aan die interne skoolorganisasie en -administrasie gegee. In die Leges het hy dit breedvoerig uiteengesit.

\section{CALVYN SE TEOLOGIESE (LEWENSBESKOULIKE) UITSPRAKE MET HULLE ONDERWYSKUNDIGE IMPLIKASIES}

Die volgende teologiese (lewensbeskoulike) uitsprake van Calvyn het onder meer onderwyskundige implikasies:

\subsection{Sy Godsbegrip: Soli Deo Gloria (aan God alleen die eer)}

God is vir Calvyn die middelpunt van alles. Hy is die Oorsprong, Wetgewer, Instandhouer, Regeerder en Doel van alle dinge (Calvyn 1960a:1-4,63; Meeter 1957: 11). Calvyn wil gevolglik alle menslike aktiwiteite (ook die onderwys) op God Drieenig rig om Hom te dien en met die hele hart, verstand en krag lief te hê (Pressly 1891:662). Vir Calvyn is die grondvraag in die lewe hoe God tot sy eer en reg kom (Calvyn 1960a:4, 5). Die antwoord op dié grondvraag is in die twee grondleerstukke aangaande die selfgenoegsaamheid en die absolute soewereiniteit van God vervat. 


\subsubsection{Die selfgenoegsaamheid van God}

God is van absoluut niks afhanklik nie. Hy is die Algenoegsame, Selfgenoegsame, Absolute Skepper en Onderhouer van die hele wêreld wat nooit deur die mens tot objek gemaak kan word nie (Calvyn 1960a:5). Handelinge 17:25 stel die saak só: Hy het ook nie nodig dat mense Hom versorg nie. Inteendeel, dit is Hy wat aan almal lewe en asem en alles gee.

\subsubsection{Die absolute soewereiniteit van God}

God is die Skepper van hemel en aarde en omdat Hy die Here van sy handewerk is, voer Hy soewereine heerskappy oor alles (Calvyn 1960a:5, 6; Brown 1965:81). In Eksodus 3:14 word hierdie soewereiniteit van God soos volg uitgedruk: Toe sê God vir Moses: 'Ek is wat Ek is....' Op grond van sy opperheerskappy is God aan niks en niemand verantwoording verskuldig nie. Hy heers oor sy handewerk na eie goeddunke, dus onafhanklik van die mens. Laasgenoemde erken hierdie soewereiniteit, buig daarvoor en handel onvoorwaardelik ooreenkomstig die gesag van God se Woord. Aangesien God absoluut soewerein is oor alles wat Hy geskape het, moet alle lewensterreine doelbewus ver-Christelik word (Calvyn 1960a:6).

Calvyn se beskouing oor God het sy siening van die onderwysdoelstelling en leerinhoud beïnvloed. Vir hom was die doel van die onderwys orn die kinders daartoe te bring om God as hulle Skepper te ken, te eer en te verheerlik en ooreenkomstig sy Woord te lewe. Die hele kind moes ook tot diens van God onderrig word.

Om God te kan ken, eer, verheerlik en lief te hê, het Hy Hom volgens Calvyn aan die mens in Skriftuur en natuur openbaar (Calvyn 1960a:17, 36). Daarom moes religieuse sowel as sekulêre vakke aan die kinders onderrig word. Naas godsdiensonderwys wat die sentrale plek in die leerinhoud moes inneem, moes lees, skryf, rekenkunde, verskeie tale, geskiedenis, etiek, retoriek, kuns, dialektiek, liggaamsopvoeding, natuurkunde of wiskunde (met die latere byvoeging van geneeskunde en regte) onderrig word (Nixon 1963:131; Dankbaar 1957:137).

\subsection{Sy Skrifbeskouing: Sola Scriptura (alleen volgens die Skrin)}

Volgens Calvyn is alles op die Woord van God gegrond (Calvyn 1960a:36). In die Skrif word God se ordening en grondplan van die werklikheid aangetref. Vanuit hierdie grondplan moet die mens sy hele lewe rig en inrig (Meeter 1957:17). Die Bybel werp sy lig op alle lewensterreine; dit geld in radikale sin vir elke faset van die mens se lewe (Calvyn 1960a:36-42).

Calvyn se beskouing oor die Skrif het sy onderwysopvattinge grootliks beinvloed. Omdat alles op die Woord van God gegrond moet wees, moet dit ook die 
grondslag van alle onderwys vorm, want alleen deur die suiwere kennis daarvan is die mens bekwaam om sy plek in die wèreld in te neem.

\subsection{Sy beskouing oor gesag en vryheid}

Calvyn sien gesag as een van die boustene in die samelewing (Calvyn 1960c:555558). Die gesag binne 'n samelewingsverband is nie aan die gesagsdraer gebind nie maar aan die gesagsamp. Laasgenoemde is met die struktuur van die betrokke samelewingsverband gegee (Calvyn 1960c:559). Die gesag van een mens oor 'n ander is nie 'n absolute gesag nie, maar slegs 'n relatiewe, verleende gesag, komende uit die absolute gesag van God. Daarom is die gesagsdraer altyd aan God verantwoordelik vir die uitoefening van gesag (Calvyn 1960c:559, 562). Die gesagsdraers moet dan so regeer dat die samelewingsverbande waarvan hulle gesagsdraers is, aan die deur God gestelde doel beantwoord (Calvyn 1960c:560).

Owerhede is instellings van God en moet as sodanig geëer word. Onderdane moet aan hulle owerheid onderdanig wees en eerbied betoon. Deur eerbied aan die owerheid te betoon, betoon die mens dit ook aan God, want Hy stel owerhede aan ooreenkomstig sy wil (Calvyn 1960c:583, 584, 590). Die owerhede moet op hulle beurt ook die eer van God bevorder omdat hulle deur sy genade regeer (Calvyn 1960c:586). Eersgenoemde het egter self 'n besondere plig teenoor hulle onderdane, naamlik om hulle billik en regverdig te regeer (Calvyn 1960c:591). Indien die owerheid nie dienooreenkomstig optree nie, kan hy tereggewys word. In dié verband wys Calvyn daarop dat ons God meer as mense moet gehoorsaam. Dit beteken dat God te alle tye gehoorsaam moet word en dat aan sy wil uitvoering gegee moet word (Calvyn 1960c:593).

Calvyn beskou die vryheid wat die mens besit, nie as onbeperkte vryheid nie (Calvyn 1960c:366,370). Die mens moet altyd verantwoordelikheid vir sy dade aanvaar (Bavinck 1956:93). Dit beteken egter nie die inboet van vryheid nie, maar 'n onderwerping aan die wetsorde van God, aan norme, wette, maatstawwe en beginsels. Gevolglik kan ware vryheid nooit in bandeloosheid ontaard nie, want menslike vryheid bestaan uit taakvervulling in die lig van en in gebondenheid aan die Woord waarin die mens se roeping deur God aan hom gegee is. Vryheid buite God en sy gebod bestaan nie. Die vryheid van die mens kan nooit absoluut wees soos God s'n nie, dit is relatief - 'n teenoor God betreklike vryheid. Die mens is alleen vry solank hy leef vir die doel waarvoor hy geskape is, te wete die eer van God (Calvyn 1960b: 370-371).

Calvyn se beskouing oor Christelike gesag en vryheid het sy siening van skoolplig en dissipline beïnvloed. Die verpligte skoolbywoning wat sedert 1536 in Genẻve vir die kinders van gemeentelede gegeld het, was nie die inboet van vryheid 
deur die ouers en die kinders nie, maar 'n onderwerping aan die wetsorde van God en die wette van die Geneefse owerheid. Immers, die mens is alleen vry solank hy leef vir die doel waarvoor hy geskape is, te wete die eer en verheerliking van God. Elke kind moes verplig word om te leer lees en skryf sodat hy in die Woord en die geloofswaarhede onderle kon word en kennis van die skepping van God kon opdoen. Op dié wyse kon hy God leer ken om Hom dan lief te hê, te eer en te verheerlik.

Die streng dissipline wat Calvyn vir sowel ouers as onderwysers voorgeskryf het, was volgens hom essensieel, want gesag is een van die boustene in die samelewing en is van God afkomstig. Die een mens oefen gesag oor die ander uit omdat God dit aan hom verleen en hy is vir die uitoefening daarvan aan God verantwoording verskuldig. Die gesaghebbers regeer dus namens God. Die ouers, onderwysers en leerlinge moes die owerhede eerbiedig wat gesag oor hulle uitoefen, want deur dit aan hulle te doen, doen hulle dit ook aan God, want Hy stel owerhede ooreenkomstig sy wil aan.

\subsection{Sy beskouing oor die samelewing}

Calvyn erken die verskeidenheid in en van die kosmos in die beginsel van soewereiniteit in eie kring (Stoker 1967:49). Dié beginsel impliseer dat die verskeidenheid in die skepping nie tot mekaar herlei kan word nie, want elke kring en terrein het sy besondere eie aard, ordinansies en bestemming. Die een mag nie oor die ander heers en hom in die uitvoering van sy taak belemmer nie (De Klerk 1972:4).

Omdat één God alles geskep het en omdat sy gedagtes absolute orde is, heers daar volgens Calvyn ook 'n Goddelike eenheid in die verskeidenheid (Cilliers 1974: 3). As gevolg hiervan vorm die skepping intrinsiek so 'n innige eenheid dat daar nie 'n skeiding tussen die verskeidenheid bewerkstellig kan word nie (Stoker 1967:50). Al het elke samelewingsverband sy eie selfstandigheid, struktuur, sin en bestemming, kruis die verbande mekaar op verskillende maniere en is onderling op verskillende wyses vervleg. Hier ontstaan 'n universele afhanklikheidsverhouding, in die sin dat die een die ander tot hulp en diens kan wees (Stoker 1961:235). Die samelewingsverbande vorm dan saam 'n onderling vervlegte en samehangende verskeidenheid (Stoker 1967:51).

Calvyn se beskouing oor die samelewing het sy siening van die onderwys beïnvloed. Ten spyte daarvan dat die skool, die kerk, die owerheid en die gesin elk sy eie aard, ordinansies en bestemming het, het hulle mekaar in die uitvoering van hulle taak nodig. Die skool het byvoorbeeld die kerk nodig om die onderwys te beheer en daaroor toesig te hou, terwyl die kerk die skool op sy beurt weer benodig om geleerde en geletterde volwassenes met kennis van die Woord van God en die Christe- 


\section{Calvyn as pedagoog}

like dogma daar te stel, sodat hulle aan hulle doel op aarde kan beantwoord, te wete om God hul Skepper te ken, te eer en te verheerlik.

\subsection{Sy beskouing oor die mens}

Calvyn sien die oorsprong, aard, wese en gesitueerdheid van die mens soos volg:

- Die mens is na die beeld van God geskape en het 'n besondere roeping om in die skepping te vervul (Calvyn 1960a:176, 177; Geldenhuys 1972:99). Die mens is geroep om God te dien, oor die wêreld te heers en laasgenoemde tot ontplooiing te bring. Die duiwel het deur verleiding die mens van God afgerokkel en hy het in sonde verval (Calvyn 1960a:244). Ten spyte van die sondeval van die mens is hy nie deur God uitgedelg nie. Deur sy goedheid, barmhartigheid en genade het God hom nog in stand gehou (Calvyn 1960a:354-355).

- Die mens is 'n liggaam-siel-eenheid waarin die liggaam ('n sterflike, aardse en konkrete entiteit wat in tyd en ruimte waargeneem kan word) en die siel ('n geestelike entiteit wat slegs indirek deur sy werking in die handelinge van die mens waarneembaar is) so innig verweef is dat hulle 'n eenheid in die menslike wese word, hoewel hulle twee afsonderlike entiteite bly (Calvyn 1960a:173, 174; Kock 1974:6-7).

- Die mens is na sy wese 'n syn-in-relasies en wel in 'n viervoudige relasie. Hy staan in relasie

- tot God:

By God begin die mens se liggaams-, siels- en geesteslewe en op Hom is dit ingestel en tot 'n eenheid saamgeweef (Calvyn 1960a:1). Sy ganse lewe word deur God beheers, bestier en bestem (Schutte 1982:7). Vir Calvyn beteken hierdie toedrag van sake dat God die mens in vennootskap met Hom neem, dog slegs in ooreenstemming met sy wil, en sodoende rus die lewensdoel van die mens in God en lewe die mens tot God se eer (Dooyeweerd 1965:190).

- tot sy naaste:

Sonder die handeling van gee en ontvang in 'n aantal van menslike verhoudinge, is dit nie moontlik om menswees soos God dit bedoel het te verwesenlik nie (Kuyper 1961:27). Die mens se naaste het 'n aanspraak op hom wat hy nie mag ontken of verontagsaam nie, want God plaas hierdie naaste opsetlik op sy weg. God gebied die mens om sy naaste lief te hê soos homself. 
- tot die wêreld:

Die moontlikheid tot kultuurskepping by die mens is daarin geleë dat sy bestaan ' $n$ bestaan in relasie tot die wêreld is (Gunter 1970:3). Aangesien die wêreld sy sin en betekenis dan net in die mens vind, kan dit ook net in sy betrokkenheid op die mens begryp word (Kuyper 1961:38). Die mens beklee 'n sentrale en unieke posisie in die wêreld en kan hoegenaamd nie buite hierdie kosmiese betrokkenheid bedink word nie (Stoker 1964:38). Die mens kan hom dus nie van die wêreld losmaak nie. Dit beteken nie dat die mens deur sy in die wêreld wees gedomineer word nie. Die mens leef in die wêreld, maar is nie 'n deel van die wêreld nie (Stoker 1964:130).

- tot homself:

Die mens se verhouding tot homself vloei ten diepste voort en is moontlik omdat die mens na die beeld van God geskape is. Saam met die mens se selfbewussyn is daar talle ander bewyse van sy verhouding tot homself: selfkennis, selfrespek, selfkritiek, selfontplooiing, selfliefde en so meer (Heyns 1978:34).

Calvyn se mensbeskouing is fundamenteel ten opsigte van sy onderwysfilosofie. Hy het die mens, ten spyte van die sondeval, as opvoedbaar beskou omdat 'n skaduwee van God se beeld na die sondeval in hom oorgebly het. Sy beskouing van die mens as 'n liggaam-siel-eenheid het sy siening van die mens as opvoedeling dwarsdeur sy lewe bemvloed, want groei en wording is deel van die menslike natuur, wat deels fisies en deels geestelik is. Beide die fisiese en geestelike komponente van die menslike natuur is vormbaar.

Uit die onderwysdoelstelling wat Calvyn gehuldig het, blyk sy siening van die mens in sy relasie tot God duidelik. Hy het geglo dat die kind daartoe gebring moes word om God sy Skepper te ken, te eer en te verheerlik en ooreenkomstig sy Woord te lewe, want die mens het sy oorsprong in God en hy is so aan God verbonde dat hy nie los van Hom kan bestaan nie.

Calvyn se siening van die mens in sy relasie tot sy medemens het sy beskouing oor gratis onderwys vir behoeftige kinders en die noodsaaklikheid van onderwys beïnvloed. Die mens kan volgens Calvyn sy menswees slegs as mens in gemeenskap verwerklik en daarom moet die mens deur middel van die onderwys vir die posisies wat hy in die kerk en die samelewing saam met sy naaste moet vervul, voorberei word.

Calvyn se beskouing oor die mens se verhouding tot die wêreld het hom die belangrikheid van sekulêre vakke in die leerplan laat besef. Deur middel van die sekulêre vakke verkry die kind kennis van die skepping ten einde hom goed van sy kultuurtaak te kan kwyt. 
Die prominente posisie wat Calvyn aan godsdiensonderwys in die leerplan toegeken het, het onder andere uit sy beskouing oor die mens se verhouding tot homself voortgevloei. Deur godsdiensonderwys kan die kind byvoorbeeld selfkennis opdoen. Die kind sal dan besef dat hy nie self die Skepper is nie, maar net die skepsel, dat hy deur God goed (met gawes en talente) geskape is, dat hy in sonde geval het en alleen deur Christus gered kan word.

\section{SAMEVATTENDE GEVOLGTREKKING}

Uit die konstruering van Calvyn se onderwysfilosofie het dit geblyk dat hy nie alleen net teoloog van formaat was nie, maar ook pedagoog. Hy het van die begin van sy openbare optrede die belangrikheid en noodsaaklikheid van die onderwys as instrument vir die bevordering van goeie openbare administrasie, die handhawing en uitbouing van die Christendom, die bevordering en behoud van menslikheid en die versekering van die kind se kultivering besef en verkondig.

Die volgende pedagogies verantwoordbare onderwysbeginsels het in sy onderwyssiening en -werksaamhede neerslag gevind:

- Die beginsel van moedertaalonderrig: Hy het die aandag daarop gevestig dat moedertaalonderrig die heel beste vir die kind is.

- Die beginsel van verpligte en gratis onderwys: Hy het verpligte onderwys vir almal en gratis onderwys vir die behoeftige leerlinge as noodsaaklik beskou ten einde elke kind daartoe in staat te stel om God sy Skepper te ken, te eer en te verheerlik en sy roeping op aarde te kan vervul.

- Die beginsel van gedifferensieerde onderwys: Hy wou aan elke kind ooreenkomstig sy besondere individualiteit onderrig verskaf.

- Hy het besondere aandag aan die interne skoolorganisasie en -administrasie gegee, omdat hy besef het dat onderwys slegs kan plaasvind indien daar 'n goed beplande organisasie en administrasie bestaan.

- Gesag en dissipline (onderwysbeheer en toesighouding) as basiese en essensiële opvoedings- en onderwysmiddel: Hy het besef dat daar geen effektiewe opvoeding en onderwys sonder doeltreffende gesag en dissipline (onderwysbeheer en toesighouding) kan plaasvind nie.

- Die beginsel van soewereiniteit in eie kring: Hy het dié beginsel in die onderwys erken, want so kan verseker word dat die samelewingsverbande en die onderwys nie aan mekaar ondergeskik gestel word nie, maar dat elkeen ' $n$ bevoegdheid op sy eie terrein, asook 'n spesifieke taak ten opsigte van die onderwys het.

- Die beginsel van die opvoeding (onderwys) van die kind in totaliteit: Hy het die onderrig en opleiding van die kind vir sowel burgerlike as kerklike leierskap 
verkondig en hom daarvoor beywer dat sekulêre vakke (bv rekenkunde, wetenskap en liggaamsopvoeding) ook in die leerplan ingesluit word.

Calvyn se besondere bydrae tot die opvoeding en onderwys was dat hy 'n Christosentriese en Skrifgefundeerde onderwysleer daargestel het.

Die Collêge Calvin (soos die Geneefse Akademie vandag bekendstaan en wat 'n sekondêre onderwysinrigting is) is 'n blywende monument van sy bydrae tot die onderwys en dien as 'n lewende voorbeeld van sy onderwysfilosofie.

\section{Literatuurverwysings}

Alexander, R C 1926. The influence of the Protestant religious education in the 16th century. New York: Vanderbilt University Press.

Bavinck, H 1956. De mens in de wetenschap. Kampen: Kok.

Brown, R M 1965. The spint of Protestantism. New York: Oxford University Press.

Cadier, J 1960. The man God mastered. London: Intervarsity Fellowship.

Calvyn, J 1949a. Commentary on I Corinthians, vol 1. Transl by J Pringle. Grand Rapids: Eerdmans.

-- 1949b. Institutes of the Christian religion, vol 2. Transl by J Allen. Grand Rapids: Eerdmans.

--- 1958. Tracts and treatises on the doctrine and worship of the church, vol 2. Transl by $\mathrm{H}$ Beveridge. Grand Rapids: Eerdmans.

--- 1960a. Institutie: Onderwijzing in de Christelijke godsdienst, eerste deel. Uit Latijn vertaald door A Sizoo. Delft: Meinema.

--- 1960b. Institutie: Ondenwizing in de Christelijke godsdienst, tweede deel. Uit Latijn vertaald door A Sizoo. Delft: Meinema.

--- 1960c. Institutie: Onderwijzing in de Christelijke godsdienst, derde deel. Uit Latijn vertaald door A Sizoo. Delft: Meinema.

Cilliers, J L Le R 1974. Calvinistiese lewens- en wêreldbeskouing en opvoedingsteorie en praktyk. Durban: SAVBO. (Monografie nr 1.)

Coetzee, J Chr 1959. Calvin and the school, in Hoogstra, J T (ed), John Calvin contemporany prophet, 197-225. Grand Rapids: Baker Bock.

Dankbaar, W F 1957. Calvijn: Zijn weg en werk. Nijkerk: Callenbach.

De Klerk, W J 1972. Roeping en werklikheid. Potchefstroom: Potchefstroom Herald.

Donyeweerd, H 1965. In the twilight of Western thought. New Jersey: Craig.

Doumergue, E 1931. Calvijn als mensch en henormer. Amsterdam: Ten Have.

Eby, F 1931. Early Protestant educators. New York: AMS Press. 
Geldenhuys, D J C 1972. Die standpunt van die N G Kerk met betrekking tot opvoeding en onderwys. DEd proefskrif, Universiteit van Suid-Afrika.

Gunter, C F G 1970. 'n Christelik-georiënteerde opvoedingsfilosofie. Stellenbosch: Universiteitsuitgewers en Boekhandelaars.

Harper, N G 1966. A Comparative study of the educational implications of the thought of John Calvin and Soren Kierkegaard. Mississippi: University of Mississippi Press.

Heyns, J A 1978. Dogmatiek. Pretoria: N G Kerkboekhandel.

Kock, P de B 1974. Die Christelike mensbeskouing. Tydsknf vir Christelike Wetenskap 10, 6-7.

Kotze, J J 1935. Calvyn en die opvoeding. Die Gereformeerde Vaandel 3/10, 307 309.

Kuyper, A 1961. Lectures on Calvinism. Grand Rapids: Eerdmans.

Marique, P J 1926. History of Christian education, vol 2. New York: Fordham University Press.

McNeill, J T 1954?. The History and character of Calvinism. New York: Oxford University Press.

Meeter, H H 1957. Het Calvinisme. Kampen: Kok.

Nixon, L 1963. John Calvin's teaching on human reason. Transl by J Allen. New York: Exposition.

Parker, T H L 1975. John Calvin: A biography. London: Dent.

Pressly, M W 1891. Calvinism and Science Article. Evangelical Repertoire, 662.

Reid, W S s a. Calvin and the founding of the Academy at Geneva. The Westminster Joumal of Theology 18, 1-33.

Scholtemeijer, H 1953. Johannes Calvyn: Die stryder vir die eer van God. Potchefstroom: Pro Rege.

Schutte, B C 1982. Onderwys in die RSA: Die pad vorentoe. Potchefstroom: PU vir CHO.

Singer, C G 1977. John Calvin: His roots and fruits. New Jersey: Presbyterian and Reformed Publishing Company.

Stoker, H G 1961. Stryd om die Ordes. Potchefstroom: Calvyn Jubileum Boekefonds.

-.. 1964. Beginsels en metodes in die wetenskap. Potchefstroom: Pro Rege.

-.- 1967. Oorsprong en rigting, band 1. Kaapstad: Tafelberg.

Towns, E L 1975. John Calvin (1509-1564), in Towns, E L (ed), A history of Religious Educators, 167-175. Grand Rapids: Baker Bock. 
Turkstra, J 1978. Een onderzoek naar de invloed van Waterink en Langeveld op het pedagogiekdenke in Zuid-Afrika. DEd proefskrif, Universiteit van SuidAfrika.

Van den Brink, J N \& Dankbaar, W F 1967. Handboek der Kerkgeschiedenis, derde deel. Den Haag: Bakker.

Van der Walt, J L 1981. Calvyn oor opvoeding en onderwys. Potchefstroom: PU vir CHO.

Walker, W 1967. John Calvin: The organiser of reformed Protestantism (1509-1564). New York: Schocken. 